\title{
An Empirical Analysis of Inventory Turnover Performance Within a Local Chinese Supermarket
}

\author{
Junaid Ali Khan \\ Shiming Deng \\ Muhammad Hammad A.K. Khan \\ Huazhong University of Science and Technology, China
}

doi: 10.19044/esj.2016.v12n34p145 URL:http://dx.doi.org/10.19044/esj.2016.v12n34p145

\begin{abstract}
Retail inventory is an important indicator for retailers as well as their shareholders and suppliers. Inventory enables retailer to sell products to customer but excessive or slow moving inventory also add extra cost. For shareholders and suppliers this is an indication of retailer's bright or grim future. The aim of this research is to analyze the inventory turnover's impact on the performance variables of profit margin percentage and sale surprise in one of the retailing firm of Hubei province China. We will study if inventory turnover is affected by profit margin percentage and sale surprise similarly across all categories and modes of operation in retail firm or there is some variation in the known behavior. We will be testing our hypothesis on data of a large local supermarket chain that operates in the Hubei province of China. They have multiple supermarkets in the tier 1 and tier 2 cities of the province. We investigate correlation of inventory turnover with profit margin percentage and sale surprise across different categories and modes of operation. The analysis reveals that there is a negative correlation between Inventory Turnover and profit margin percentage, while positive correlation exists between Inventory Turnover and Sale surprise across all categories and modes. But its rate of correlation varies between categories and channel structure.
\end{abstract}

Keywords: Inventory turnover, profit margin percentage, sale surprise, supermarket

\section{Introduction}

Inventory being one of the most important variable as it accounts for a significant percentage of the assets of a retail firm. On average, inventory represents more than $35 \%$ of total assets of a firm and around $50 \%$ of current assets for retailers. Because of that retailers do focus on productivity of 
inventory to have competitive edge (Yasin Allen et al, 2013). The research of Namazi et al (2011) indicated a significant reverse relationship between changes in inventory and short-term changes in corporate profits.

Inventory management processes are continuously under improvement by retailers to reduce their inventory levels. According to Standard \& Poor's industry review on general retailing (Sack 2000), "Merchandise inventories are a retailer's most important asset, even though buildings, property and equipment usually exceed inventory value in dollar terms." How much important inventory management is to the retailers cannot be more emphasized.

One of the criteria that the managers and industry analysts by which they judge the performance of retailer is, Inventory turnover. Which is defined as the ratio between value of goods sold to average inventory. Gaur, Fisher and Raman (2005), conducted an explanatory investigation of inventory turnover performance of publicly listed retailers in America. They found that not only across firms but also within firms inventory turnover varies with time. They further showed that a large fraction of the variation in inventory turnover can be explained by three performance variables obtained from public financial data: gross margin (the ratio of gross profit net of markdowns to net sales), capital intensity (the ratio of average fixed assets to average total assets), and sales surprise (the ratio of actual sales to expected sales for the year). They use the estimation results to propose a metric for benchmarking inventory productivity of retail firms.

In this paper we investigate the effects of profit margin percentage and sale surprise on inventory turnover performance of Chinese supermarket chain. Gaur, Fisher and Raman (2005), showed that inventory turnover is negatively correlated with profit margin percentage and positively correlated with sale surprise across different firms. However, to our knowledge, there are no research papers using real data to estimate the effect of profit margin percentage and sale surprise on inventory turnover within a Chinese supermarket across different categories of product and modes of operation.

The main aim of our paper is to re-test the hypotheses in Gaur, Fisher and Raman (2005), regarding gross margin and sales surprise on our data set. We are doing it because we use a dataset that is more detailed as we test these hypotheses for different product categories and modes of operation. Our results for these tests are consistent with those obtained by Gaur, Fisher and Raman (2005). First, we find that inventory turnover is negatively correlated with profit margin percentage and positively correlated with sale surprise. But among different categories in food and non-food section this correlation varies. This variation can be explained by the difference in retail pricing and other performance variables. 
Our paper contributes to the academic literature by extending the retesting the hypothesis in Gaur, Fisher and Raman (2005) for empirical research on inventory productivity in local Chinese supermarket setting. The models for different categories and modes of operation employed in this paper are helpful to retail managers for comparing inventory turnover performance within supermarkets.

In this study we have used data from a local Chinese supermarket, which sell products in different categories under different mode of operations. Although confined to single retailer, this kind of empirical analysis on point of sale data enables us to directly test the impact of inventory turnover performance in different product categories within a supermarket. In our study we will focus on multiple categories belong to food and non-food section.

\section{Literature Review}

Inventory, sales and profit have significant relationship among them and the product inventory structure show some relationship with profit and sales, Bernard and Noel (1991). In the recent years, many studies in operations management have tried to look at firm performance by analyzing firm level data of inventories and other financial data. Event based studies were the earliest studies on effect of operational decision on performance of firm using public financial data (Hendricks and Singhal, 1996). Vergin (1998) analyzed trends in inventory turnover ratios in fortune 500 companies. Studies after 2000 tried to look at relationship between turnover ratios and other business variables. Fleisch and Tellkamp (2005) explained the effect of inventory inaccuracy on supply chain performance. Gaur et al. (2005) used financial data to demonstrate that inventory turnover ratio varies widely across industry segments and is influenced by variations in gross margin, sales surprise and capital intensity. They propose an econometric model to investigate the determinants of inventory turnover in US retail industry and consider gross margin, sales surprise and capital intensity as explanatory variables. It is suggested that changes in the explanatory variables should be incorporated with the inventory turnover data to evaluate the inventory productivity of a firm.

Roumiantsev and Netessine (2007) test some of the academic insights derived from traditional inventory models developed at the product level by using quarterly data from public American companies. They use a timeseries study to show that inventory levels are positively correlated with demand uncertainty, lead times, and gross margins. They also find evidence for economies of scale as larger firms carry relatively lower levels of inventory compared to smaller firms. 
These studies suggest a negative correlation between inventory turnover ratio and gross margin. The other hypotheses suggest that inventory turnover ratio is positively correlated to capital intensity, sales surprise and company size in terms of previous year's sales. An additional hypothesis on effect of sales growth on inventory turnover ratio is proposed to be effective in the sales growth region, rather than the sales decline region.

Kiracı (2009) showed a positive relationship between inventory turnover and return on assets and net profit margin and a negative relationship between inventory turnover and gross profit margin. In the study lead by Lazaridis and Tryfonidis(2006), a significant relationship between cash conversion period and gross profit margin is showed. In the Raheman and Nasr(2007) study, there is a negative relationship between inventory holding period and firm's profitability.

Boute et al. (2007) find that inventory turnover is notably higher in retailer than wholesale, during their cross-sectional study of analyzing the difference in inventory turnover between retail and wholesale sector. By analyzing the data of 722 firms, Rumyantsev and Netessine (2007) find that the firms, which operate with, demand uncertainty, longer lead times and higher gross margin have larger inventories compared to those firms that doesn't.

Firm's annual inventory turnover has correlation with its performance in retail industry Aghazadeh (2009). Future stock performance could be predicted by modification of annual inventory turnover of the firms. Various firms in different sections are evaluated in terms of their inventory turnover ratios. Aghazadeh sums up that both stock performance and management quality of firms' are affected positively, if managers are able to control inventory turnover.

There is an increasing literature that investigates inventory at firm level rather than that at the product/category level as we do in our study. Our paper contributes to this research area by extending the model of Gaur et al. (2005) and testing it at product/category level. We review numerous aspects that could result in positive or negative correlations of profit margin percentage and sale surprise with inventory turnover. Our results are helpful to retailers to measure their performance variations in different categories.

\section{Data \& Variable Description}

We use transaction sales data from one of the biggest Chinese retailer store chain in China Hubei Province. The data drawn from their internal database comprise of 41 months. It includes the information about sales of products belonging to 27 different products categories (food and non food) and store containing over 20,000 products at a time. Most of the categories are operated under Distribution and Reseller mode. In reseller mode the 
retailer acts in a traditional way, buy products from manufacturer/supplier and then sell them to customer. In Distribution mode the product inventory and pricing is control by the manufacturer/supplier and retailer get paid as some percentage of total revenue for using the retailer shelf.

Our raw data contained over 0.3 million observations in food section which were divided among 15 categories, while 0.4 million observations in non-food section comprising of 12 categories. After initial data inspection and cleaning missing and duplicated observations were removed. For the purpose of this study we only selected those categories among food and nonfood section, which were contributing more to the sale revenue generation. Within each category we also excluded those products/brands from our dataset, which were not available in our store for more than 6 months during period of 2013-2016. We compared the pricing and inventory turnover of selected products with the overall category and didn't find any significant change. Therefore we believe that the omission of other products/brands should not have a substantial effect on the empirical results.

Our final food section dataset contains almost 162,000 observations in 7 categories and non-food section around 124,000 in 4 categories. Tables below present summary statistics of our final dataset.

Table 8

\begin{tabular}{cc}
\hline Non-food Categories & Share of revenue (\%) \\
\hline Cosmetic and washing products & 58.15 \\
Textile & 16.19 \\
Tissue paper & 19.16 \\
Home appliance & 0.19 \\
Baby category & 6.31 \\
\hline
\end{tabular}

Table 9

\begin{tabular}{cc}
\hline Food Categories & Share of revenue (\%) \\
\hline Fruits and Vegetables & 3.09 \\
Livestock & 9.17 \\
Fisheries & 0.14 \\
Food & 0.33 \\
Daily use food & 17.28 \\
Grains and oil & 23.55 \\
Seasonings & 4.65 \\
Canned food & 0.73 \\
Tobacco \& Alcohol & 16.15 \\
Candy \& Cookies & 8.82 \\
Snacks & 3.16 \\
Beverages & 12.93 \\
\hline
\end{tabular}

Summary of some of the important variables is shown below. 
Table 10

\begin{tabular}{|c|c|c|c|c|c|c|}
\hline Section & \multicolumn{2}{|c|}{$\begin{array}{c}\text { Retail Price } \\
\text { (RMB) }\end{array}$} & \multicolumn{2}{|c|}{$\begin{array}{c}\text { Inventory Turn Over } \\
\text { (Per month) }\end{array}$} & \multicolumn{2}{c|}{$\begin{array}{c}\text { Profit Margin } \\
\text { (\%) }\end{array}$} \\
\hline Food Category & Mean & SD & Mean & SD & Mean & SD \\
\hline Livestock & 20.5 & 14 & 2 & 3.9 & 11 & 76.6 \\
\hline Daily Use Food & 11.5 & 11.4 & 2.5 & 3.9 & 16.6 & 13 \\
\hline Grains \& Oil & 20.7 & 28.5 & 1.2 & 2.1 & 16.9 & 15.8 \\
\hline Seasoning & 8.6 & 9.8 & 0.8 & 1.5 & 22.2 & 12.1 \\
\hline Tobacco \& Alcohol & 55.7 & 94.7 & 1.1 & 1.9 & 21 & 10.2 \\
\hline Candy \& Cookies & 11 & 13.9 & 0.9 & 1.5 & 20.2 & 11.4 \\
\hline Beverages & 37.1 & 61.4 & 1 & 1.8 & 17 & 13.8 \\
\hline
\end{tabular}

Table 11

\begin{tabular}{|c|c|c|c|c|c|c|}
\hline Section & \multicolumn{2}{|c|}{$\begin{array}{c}\text { Retail Price } \\
\text { (RMB) }\end{array}$} & \multicolumn{2}{c|}{$\begin{array}{c}\text { Inventory Turn Over } \\
\text { (Per month) }\end{array}$} & \multicolumn{2}{c|}{$\begin{array}{c}\text { Profit Margin } \\
\text { (\%) }\end{array}$} \\
\hline Non-food Category & Mean & SD & Mean & SD & Mean & SD \\
\hline Washing Products & 21.2 & 20 & 0.83 & 1.52 & 19.2 & 11.5 \\
\hline Textile Products & 29.7 & 46 & 0.68 & 1.07 & 29.1 & 12.6 \\
\hline Tissues Products & 9 & 6.1 & 0.79 & 1.57 & 18.6 & 13.3 \\
\hline Baby Products & 23.8 & 21.7 & 0.82 & 1.31 & 23.9 & 9.6 \\
\hline
\end{tabular}

The inventory turnover (ITO) indicates how many times the inventories are turned over, sold and reproduced over the observation period (Krasulja \& Ivanisevic, 2005). In retail companies, it is the relative ratio of the purchase price, i.e. cost of goods sold (CGS) to the average amount of inventories over the period, one year in most cases but in our study its one month, which gives better estimate of average amount of inventories.

\section{Research Hypothesis \& Model Specification}

In this section of article we prepare the hypotheses to relate Inventory turnover with profit margin percentage and sale surprise in different categories. Studying category-by-category variations in profit margin percentage, sale surprise and other performance variables gives our model an important distinction, because most of the other studies are done at retailer level. As Gaur et al. (2005) noted that firm-level cumulative variables have numerous shortcomings that limit their effectiveness. In our study those limitations has been removed.

\section{H1: Inventory turnover is negatively correlated with profit margin percentage}

Profit margin percentage represents the fraction of total sales revenue that the firm retains after incurring the direct costs. The higher the profit margin percentage is, the more efficient firm is. Retailers would be inclined to carry more inventory for products with higher profit margins as they would want to reduce or eliminate the number of stock- outs. There are many 
studies which show that at firm-level inventory turnover is negatively correlated with profit margin percentage. Gaur et al. (2005) test this hypothesis using the firm-level data from period 1985-2009. Using detailed and more recent data set, we would like to find consistency among different categories and compare the current results to them.

\section{H2: Inventory turnover is positively correlated with sales surprise.}

Inventory turnover can fluctuate by surprisingly high sales. Sales surprise is ratio of actual sales to sales forecast. Sales surprise will increase if actual sales are higher than the forecasted sale. If the sales quantity in a certain period is higher than its forecast, then the average inventory level for that period will be lower than expected, and inventory turnover will be higher than expected. Alternatively, if the sales surprise is small, we would have a one time reduction in the inventory turnover for that month as there would be an inventory build-up.

Using our category level data we would like to test if profit margin percentage and sales surprise affects the inventory turnover in the same way or not in different kind of products within one retailer.

\section{Results}

Table 5,6 below shows the Analysis of Variance for food and nonfood section between Inventory turnover and categories. Large F value and small $\mathrm{P}$ value of ANOVA suggest that variation of Inventory Turnover among different categories is much larger than variation of Inventory Turnover within each category. So there is significant relationship between different categories and Inventory Turnover.

Table.7-10 shows linear regression model for food and non-food section categories in Reseller and Distribution modes. All of these models proves our Hypothesis 1 and 2 that Inventory turnover is negatively correlated with profit margin percentage and Inventory turnover is positively correlated with sales surprise. Except for Candy \& Cookies category, it shows no significant relation between Inventory turnover and Profit margin percentage in reseller mode. Tobacco and wine category also didn't show significant relationship between Inventory turnover and sale surprise in distribution mode.

All the linear regression models have low R-squared values. Generally it is thought that low R-squared values represent bad models. In some context this rule will make sense but not as a general rule. R-squared is a statistical measure of how close the data are to the fitted regression line. Consider Figure 1, it's a scatterplot between Inventory turnover and Profit margin and it clearly shows a negative correlation but a scattered one. So it explains the significant relationship between the two variables but making a 
precise prediction based on this model will be problematic. The reason for the scattered point is that within each category there are multiple subcategories, each sub-category holds dozens of different brands and each brand has many products with its unique pricing strategy which gives different profit margin and inventory turnover values.

All these models show that Inventory turnover is affected by profit margin percentage and sale surprise with different rates. One thing to note is that the rate at which inventory turnover is affected by profit margin percentage is higher in reseller mode than the distribution mode. It means one unit change in profit margin percentage will have more affect on inventory turnover in reseller mode than at distribution mode.

Figure 8. ITO vs Profit Margin Percentage

Table 12

\begin{tabular}{|c|c|c|c|c|c|}
\hline & \multicolumn{5}{|c|}{ Analysis of variance } \\
\hline & \multicolumn{5}{|c|}{ Food Section } \\
\hline & Df & Sum Sq & Mean Sq & F value & $\operatorname{Pr}(>F)$ \\
\hline Category & 6 & 56436 & 9406 & 1780 & $<2 \mathrm{e}-16 * * *$ \\
\hline Residuals & 161875 & 855159 & 5 & & \\
\hline $\begin{array}{l}\text { Signif. } \\
\text { Codes: }\end{array}$ & \multicolumn{5}{|c|}{0 ‘***’ 0.001 ‘**’ 0.01 '*’ 0.05 '?' 0.1 ' ' 1} \\
\hline
\end{tabular}

Table 13

\begin{tabular}{|c|c|c|c|c|c|}
\hline & \multicolumn{5}{|c|}{ Analysis of variance } \\
\hline & \multicolumn{5}{|c|}{ Non-Food Section } \\
\hline & Df & Sum Sq & Mean Sq & F value & $\operatorname{Pr}(>F)$ \\
\hline Category & 4 & 399 & 99.70 & 48.61 & $<2 \mathrm{e}-16 * * *$ \\
\hline Residuals & 123841 & 253988 & 2.05 & & \\
\hline $\begin{array}{l}\text { Signif. } \\
\text { Codes: }\end{array}$ & & $0^{\text {‘***' }} 0.0$ & ' 0.01 '*' & ' 0.1 ، & \\
\hline
\end{tabular}


Table 14

\begin{tabular}{|c|c|c|c|c|}
\hline \multicolumn{5}{|c|}{$\begin{array}{c}\text { Non-Food Section: Reseller Mode } \\
\text { Dependent variable: }\end{array}$} \\
\hline & \multicolumn{4}{|c|}{ Inventory Turnover } \\
\hline & Baby Products & $\begin{array}{l}\text { Cosmetics \& } \\
\text { Washing }\end{array}$ & Textile & Tissues \\
\hline Profit margin \% & $\begin{array}{l}-1.097^{* * *} \\
(0.185)\end{array}$ & $\begin{array}{c}-1.849^{* * *} \\
(0.103)\end{array}$ & $\begin{array}{c}-1.834^{* * *} \\
(0.130)\end{array}$ & $\begin{array}{c}-3.543^{* * *} \\
(0.546)\end{array}$ \\
\hline Retail Price & $\begin{array}{l}-0.002^{* * *} \\
(0.001)\end{array}$ & $\begin{array}{l}-0.005^{* * *} \\
(0.0003)\end{array}$ & $\begin{array}{l}-0.002^{* * *} \\
(0.0002)\end{array}$ & $\begin{array}{c}0.004 \\
(0.006)\end{array}$ \\
\hline Sale Surprise & $\begin{array}{l}0.148^{* * *} \\
(0.007)\end{array}$ & $\begin{array}{l}0.082^{* * *} \\
(0.002)\end{array}$ & $\begin{array}{l}0.055^{* * *} \\
(0.002)\end{array}$ & $\begin{array}{l}0.044^{* * *} \\
(0.007)\end{array}$ \\
\hline Constant & $\begin{array}{l}0.930^{* * *} \\
(0.051)\end{array}$ & $\begin{array}{l}1.202^{* * *} \\
(0.023)\end{array}$ & $\begin{array}{l}1.098^{* * *} \\
(0.037)\end{array}$ & $\begin{array}{l}1.317^{* * *} \\
(0.146)\end{array}$ \\
\hline Observations & 10,998 & 38,161 & 15,460 & 1,726 \\
\hline $\mathrm{R}^{2}$ & 0.047 & 0.057 & 0.069 & 0.059 \\
\hline Adjusted $\mathrm{R}^{2}$ & 0.047 & 0.057 & 0.069 & 0.057 \\
\hline Residual & 1.277 & 1.401 & 0.933 & 1.457 \\
\hline Std. Error & $(\mathrm{df}=10994)$ & $(\mathrm{df}=38157)$ & $(\mathrm{df}=15456)$ & $(\mathrm{df}=1722)$ \\
\hline F Statistic & $\begin{array}{c}180.911^{* * *} \\
(\mathrm{df}=3 ; 10994)\end{array}$ & $\begin{array}{c}763.020^{* * *} \\
(\mathrm{df}=3 ; 38157)\end{array}$ & $\begin{array}{c}381.087^{* * *} \\
(\mathrm{df}=3 ; 15456)\end{array}$ & $\begin{array}{c}35.735^{* * *} \\
(\mathrm{df}=3 ; 1722)\end{array}$ \\
\hline Note: & & ${ }^{*} \mathrm{p}<0.1 ;{ }^{* *} \mathrm{p}<0$. & ${ }^{* *} \mathrm{p}<0.01$ & \\
\hline
\end{tabular}

Table 15

\begin{tabular}{|c|c|c|c|c|}
\hline \multicolumn{5}{|c|}{$\begin{array}{r}\text { Non-Food Section: Distribution Mode } \\
\text { Dependent variable: }\end{array}$} \\
\hline & \multicolumn{4}{|c|}{ Inventory Turnover } \\
\hline & Baby Products & $\begin{array}{l}\text { Cosmetics \& } \\
\text { Washing }\end{array}$ & Textile & Tissues \\
\hline Profit margin \% & $\begin{array}{c}-0.473^{* * *} \\
(0.161)\end{array}$ & $\begin{array}{c}-0.782^{* * *} \\
(0.055)\end{array}$ & $\begin{array}{c}-0.857^{* * *} \\
(0.089)\end{array}$ & $\begin{array}{c}-0.727^{* * *} \\
(0.109)\end{array}$ \\
\hline Retail Price & $\begin{array}{c}-0.004^{* * *} \\
(0.001)\end{array}$ & $\begin{array}{c}-0.005^{* * *} \\
(0.001)\end{array}$ & $\begin{array}{c}0.001^{* *} \\
(0.0003)\end{array}$ & $\begin{array}{l}-0.001 \\
(0.003)\end{array}$ \\
\hline Sale Surprise & $\begin{array}{l}0.064^{* * *} \\
(0.010)\end{array}$ & $\begin{array}{l}0.071^{* * *} \\
(0.002)\end{array}$ & $\begin{array}{c}0.053^{* * *} \\
(0.004)\end{array}$ & $\begin{array}{l}0.034^{* * *} \\
(0.002)\end{array}$ \\
\hline Constant & $\begin{array}{l}0.993^{* * *} \\
(0.070)\end{array}$ & $\begin{array}{l}0.922^{* * *} \\
(0.018)\end{array}$ & $\begin{array}{c}0.935^{* * *} \\
(0.042)\end{array}$ & $\begin{array}{c}0.879^{* * *} \\
(0.035)\end{array}$ \\
\hline Observations & 2,775 & 38,046 & 6,280 & 10,356 \\
\hline $\mathrm{R}^{2}$ & 0.021 & 0.057 & 0.048 & 0.043 \\
\hline Adjusted $\mathrm{R}^{2}$ & 0.020 & 0.057 & 0.047 & 0.043 \\
\hline Residual Std. & 1.292 & 1.542 & 1.277 & 1.545 \\
\hline
\end{tabular}




\begin{tabular}{|ccccc|}
\hline Error & $(\mathrm{df}=2771)$ & $(\mathrm{df}=38042)$ & $(\mathrm{df}=6276)$ & $(\mathrm{df}=10352)$ \\
F Statistic & $20.249^{* * *}$ & $772.758^{* * * *}$ & $104.479^{* * * *}$ & $155.102^{* * *}$ \\
& $(\mathrm{df}=3 ; 2771)$ & $(\mathrm{df}=3 ; 38042)$ & $(\mathrm{df}=3 ; 6276)$ & $(\mathrm{df}=3 ; 10352)$ \\
& & ${ }^{*} \mathrm{p}<0.1 ;{ }^{* *} \mathrm{p}<0.05 ;{ }^{* * *} \mathrm{p}<0.01$ & \\
Note: & & &
\end{tabular}

Table 16

\begin{tabular}{|c|c|c|c|c|c|c|}
\hline \multicolumn{7}{|c|}{$\begin{array}{l}\text { Food Section: Reseller Mode } \\
\text { Dependent variable: }\end{array}$} \\
\hline & & & Inventory & Turnover & & \\
\hline & $\begin{array}{l}\text { Candy \& } \\
\text { Cookies }\end{array}$ & $\begin{array}{l}\text { Daily use } \\
\text { food }\end{array}$ & Beverages & $\begin{array}{l}\text { Grains \& } \\
\quad \text { Oils }\end{array}$ & Seasoning & $\begin{array}{c}\text { Tobacco \& } \\
\text { Alcohol }\end{array}$ \\
\hline \multirow{2}{*}{$\begin{array}{c}\text { Profit } \\
\text { margin \% }\end{array}$} & -0.529 & $-4.480^{* * *}$ & $-3.041^{* * *}$ & $-5.676^{* * *}$ & $-1.178^{* * *}$ & $-2.357^{* * *}$ \\
\hline & $(0.414)$ & (1.670) & (0.298) & (0.358) & (0.168) & (0.344) \\
\hline Retail Price & $\begin{array}{l}-0.012^{* * *} \\
(0.002)\end{array}$ & $\begin{array}{l}-0.004 \\
(0.002)\end{array}$ & $\begin{array}{l}-0.001^{* * *} \\
(0.0003)\end{array}$ & $\begin{array}{c}-0.008^{* * *} \\
(0.001)\end{array}$ & $\begin{array}{l}-0.005^{* * *} \\
(0.001)\end{array}$ & $\begin{array}{l}-0.002^{* * *} \\
(0.0003)\end{array}$ \\
\hline \multirow{2}{*}{$\begin{array}{c}\text { Sale } \\
\text { Surprise }\end{array}$} & $0.023^{* * *}$ & $0.027^{* *}$ & $0.023^{* * *}$ & $0.003^{* * *}$ & $0.020^{* * * *}$ & $0.011^{* * *}$ \\
\hline & (0.003) & $(0.011)$ & $(0.001)$ & $(0.0003)$ & $(0.002)$ & $(0.001)$ \\
\hline Constant & $\begin{array}{l}1.161^{* * *} \\
(0.092)\end{array}$ & $\begin{array}{l}1.914^{* * *} \\
(0.305)\end{array}$ & $\begin{array}{l}1.414^{* * *} \\
(0.055)\end{array}$ & $\begin{array}{l}2.281^{* * *} \\
(0.069)\end{array}$ & $\begin{array}{l}1.000^{* * *} \\
(0.038)\end{array}$ & $\begin{array}{l}1.447^{* * *} \\
(0.078)\end{array}$ \\
\hline Observations & 8,100 & 761 & 10,351 & 8,281 & 16,120 & 6,579 \\
\hline $\mathrm{R}^{2}$ & 0.012 & 0.018 & 0.036 & 0.043 & 0.015 & 0.033 \\
\hline Adjusted $\mathrm{R}^{2}$ & 0.012 & 0.014 & 0.036 & 0.043 & 0.014 & 0.032 \\
\hline Residual & 1.577 & 1.657 & 1.517 & 2.088 & 1.164 & 1.534 \\
\hline Std. Error & $(\mathrm{df}=8096)$ & $(\mathrm{df}=757)$ & $(\mathrm{df}=10347)$ & $(\mathrm{df}=8277)$ & $\begin{array}{c}(\mathrm{df}= \\
16116)\end{array}$ & $\begin{array}{c}(\mathrm{df}= \\
6575)\end{array}$ \\
\hline F Statistic & $\begin{array}{c}33.873^{* * *} \\
(\mathrm{df}=3 \\
8096)\end{array}$ & $\begin{array}{c}4.557^{* * *} \\
(\mathrm{df}=3 \\
757)\end{array}$ & $\begin{array}{c}130.216^{* * *} \\
(\mathrm{df}=3 \\
10347)\end{array}$ & $\begin{array}{c}123.732^{* * *} \\
(\mathrm{df}=3 \\
8277)\end{array}$ & $\begin{array}{c}79.469^{* * *} \\
(\mathrm{df}=3 \\
16116)\end{array}$ & $\begin{array}{c}74.081^{* * *} \\
(\mathrm{df}=3 \\
6575)\end{array}$ \\
\hline Note: & & & ${ }^{*} \mathrm{p}<0.1 ;{ }^{* *} \mathrm{p}$ & $5 ;{ }^{* * *} \mathrm{p}<0.01$ & & \\
\hline
\end{tabular}

Table 17

\begin{tabular}{|c|c|c|c|c|c|c|}
\hline \multicolumn{7}{|c|}{$\begin{array}{r}\text { Food Section: Distribution Mode } \\
\text { Dependent variable: }\end{array}$} \\
\hline & $\begin{array}{l}\text { Candy \& } \\
\text { Cookies }\end{array}$ & $\begin{array}{l}\text { Daily use } \\
\text { food }\end{array}$ & $\begin{array}{r}\text { Inventor } \\
\text { Beverages }\end{array}$ & $\begin{array}{l}\text { urnover } \\
\text { Grains \& } \\
\text { Oils }\end{array}$ & Seasoning & $\begin{array}{l}\text { Tobacco } \\
\text { \& Alcohol }\end{array}$ \\
\hline \multirow{2}{*}{$\begin{array}{c}\text { Profit } \\
\text { margin \% }\end{array}$} & $-0.654^{* * *}$ & $-4.833^{* * *}$ & $-0.661^{* * * *}$ & $-1.408^{* * *}$ & $-0.701^{* * *}$ & $-1.821^{* * *}$ \\
\hline & (0.069) & (0.184) & $(0.082)$ & $(0.092)$ & $(0.082)$ & $(0.231)$ \\
\hline \multirow{2}{*}{$\begin{array}{l}\text { Sale } \\
\text { Surprise }\end{array}$} & $0.015^{* * *}$ & $0.003^{* *}$ & $0.004^{* * *}$ & 0.00004 & $0.023^{* * *}$ & -0.00001 \\
\hline & $(0.001)$ & $(0.001)$ & $(0.0004)$ & $(0.00003)$ & $(0.002)$ & $(0.001)$ \\
\hline
\end{tabular}




\begin{tabular}{|c|c|c|c|c|c|c|}
\hline Retail Price & $\begin{array}{c}-0.004^{* * * *} \\
(0.001)\end{array}$ & $\begin{array}{c}-0.024^{* * * *} \\
(0.002)\end{array}$ & $\begin{array}{l}-0.002^{* * * *} \\
(0.0002)\end{array}$ & $\begin{array}{c}-0.002^{* * * *} \\
(0.001)\end{array}$ & $\begin{array}{c}-0.013^{* * *} \\
(0.003)\end{array}$ & $\begin{array}{c}-0.0002 \\
(0.0003)\end{array}$ \\
\hline Constant & $\begin{array}{l}1.058^{* * *} \\
(0.018)\end{array}$ & $\begin{array}{c}3.644^{* * *} \\
(0.048)\end{array}$ & $\begin{array}{l}1.213^{* * *} \\
(0.021)\end{array}$ & $\begin{array}{l}1.496^{* * *} \\
(0.028)\end{array}$ & $\begin{array}{l}1.160^{* * *} \\
(0.031)\end{array}$ & $\begin{array}{l}1.687^{* * *} \\
(0.057)\end{array}$ \\
\hline Observations & 25,175 & 25,895 & 18,583 & 14,760 & 17,284 & 4,491 \\
\hline $\mathrm{R}^{2}$ & 0.015 & 0.030 & 0.011 & 0.016 & 0.012 & 0.014 \\
\hline Adjusted $\mathrm{R}^{2}$ & 0.015 & 0.029 & 0.011 & 0.016 & 0.012 & 0.013 \\
\hline Residual & 1.412 & 3.916 & 1.863 & 2.090 & 1.697 & 2.212 \\
\hline Std. Error & $\begin{array}{c}(\mathrm{df}= \\
25171)\end{array}$ & $\begin{array}{c}(\mathrm{df}= \\
25891)\end{array}$ & $\begin{array}{c}(\mathrm{df}= \\
18579)\end{array}$ & $\begin{array}{c}(\mathrm{df}= \\
14756)\end{array}$ & $\begin{array}{c}(\mathrm{df}= \\
17280)\end{array}$ & $\begin{array}{l}(\mathrm{df}= \\
4487)\end{array}$ \\
\hline F Statistic & $\begin{array}{c}127.814^{* * *} \\
(\mathrm{df}=3 \\
25171)\end{array}$ & $\begin{array}{c}263.142^{* * *} \\
(\mathrm{df}=3 ; \\
25891)\end{array}$ & $\begin{array}{c}70.820^{* * * *} \\
(\mathrm{df}=3 ; \\
18579)\end{array}$ & $\begin{array}{c}79.135^{* * *} \\
(\mathrm{df}=3 \\
14756)\end{array}$ & $\begin{array}{c}68.990^{* * *} \\
(\mathrm{df}=3 ; \\
17280)\end{array}$ & $\begin{array}{c}20.875^{* * * *} \\
(\mathrm{df}=3 \\
4487)\end{array}$ \\
\hline Note: & \multicolumn{6}{|c|}{${ }^{*} \mathrm{p}<0.1 ;{ }^{* *} \mathrm{p}<0.05 ;{ }^{* * *} \mathrm{p}<0.01$} \\
\hline
\end{tabular}

\section{Conclusion}

As per earlier studies, appropriate inventory management can be important in creating value for the firms. Inventory turnover, which can be a benchmark to measure inventory productivity, indicates that the company can sell its inventory numerous times a year and will replenish them again. The results of this study indicate that inventory turnover has a negative correlation with profit margin percentage and a positive correlation with sale surprise with varying rate of change.

This study has some potential limitations. Although we used category level data compared to aggregate data at firm level by other studies, there is still an aggregate effect because of multiple sub-categories and brand within each category. Analysis carried out on such a data cannot capture operational aspects important in inventory management like product variety, brand size.

To our knowledge this has been the first empirical study that shows the variation in correlation within different categories belong to food and non-food section for different modes of operation. The results of this study can be used to identify methods and practices to improve inventory performance within supermarket for different categories.

\section{References:}

1. Abhishek, V., Jerath, K., \& Zhang, Z. J. (2015). Agency selling or reselling? Channel structures in electronic retailing. Management Science.

2. Alan, Y., Gaur, V., \& Gao, G. (2011). Does inventory turnover predict future stock returns. Working paper, Cornell University, Ithaca, NY. 
3. Balakrishnan R, Linsmeier TJ, Venkatachalam M. 1996. Financial benefits from JIT adoption: Effects of customer concentration and cost structure. Accounting Review 183-205.

4. Bernard V, Noel J.1991. "Do Inventory Disclosures Predict Sales and Earnings?” Journal of Accounting, Auditing and Finance. Pp. 82-145.

5. Cachon, G. P. 2003.Supply chain coordination with contracts. de Kok A. G., S. C. Graves, eds. Supply Chain Management: Design, Coordination and Operation. Elsevier Science, Amsterdam, NorthHolland, 229-339.

6. Cachon, G. P., M. A. Lariviere. 2005. Supply chain coordination with revenue-sharing contracts: Strengths and limitations. Management Sci. 51(1): 30-44.

7. Chen H, Frank MZ, Wu OQ. 2007. U.S. retail and wholesale inventory performance from 1981 to 2004. Manufacturing \& Service Oper. Management. 9(4): 430-456

8. Dong, Y., M. Dresner, Y. Yao. 2014. Beyond information sharing: An empirical analysis of vendor-managerd inventory. Prod. Oper. Manag. 23(5): 817-828.

9. Fama F .Eugene, French Kenneth R.1992. The cross-section of expected stock returns. Journal of Finance- June

10. Fisher, M. L., A. Raman, and A. McClelland. 2000. Rocket Science Retailing is Almost Here - Are You Ready? Harvard Business Review, July/August.

11. Gaur, V., Fisher, M. L., \& Raman, A. (2005). An econometric analysis of inventory turnover performance in retail services. Management science, 51(2), 181-194.

12. Gaur, V., Kesavan, S., \& Raman, A. (2014). Retail Inventory. California Management Review, 56(2), 55-76.

13. Hendricks, K. B., V. R. Singhal. 2001. The Long-run Stock Price Performance of Firms with Effective TQM Programs as Proxied by Quality Award Winners. Management Science, 47, 359-368.

14. Jerath, K., Z. J. Zhang. 2010. Store-within-a-store. J. Mark. Res. 47(4): 748-763.

15. Kenan-Flagler Business School Research Paper No. 2013-5 Shanshan H, et al.2010. "Supply Chain Structure, Inventory Turnover, and Financial Performance: Evidence from Manufacturing Companies in China"

16. Kurtulus, M., R. C. Savaskan. 2013.Drivers and implications of direct-store-delivery in distribution channel. Working paper, Owen Graduate School of Management, Vanderbilt University. 
17. Kurtulus, M., A. Nakkas, S. Ulku. 2014. The value of category captainship in the presence of manufacturer competition. Prod. Oper. Manag. 23(3): 420-430.

18. Li, J., Chan, T. Y., \& Lewis, M. (2016). What Happens When Manufacturers Perform The Retailing Functions?. Production and Operations Management.

19. McGahan, A. M., M. E. Porter. 1997. How much does industry matter, really? Strategic Management Journal, 18, 15-30.

20. Rajagopalan, S., A. Malhotra. 2001. Have U.S. Manufacturing Inventories Really Decreased? An Empirical Study. Manufacturing \& Service Operations Management, 3, 14-24. 